\title{
Review
}

\section{Effectiveness of autoclaving in sterilizing reusable medical devices in healthcare facilities}

\author{
Gopal Panta ${ }^{1}$, Ann K Richardson², Ian C Shaw ${ }^{3}$ \\ ${ }^{1}$ School of Health Sciences, University of Canterbury, Christchurch, New Zealand \\ ${ }^{2}$ School of Health Sciences, University of Canterbury, Christchurch, New Zealand \\ ${ }^{3}$ School of Physical and Chemical Sciences, University of Canterbury, Christchurch, New Zealand
}

\begin{abstract}
Medical devices are sterilized before being used for invasive clinical procedures such as surgery, to prevent pathogen transfer. Failure to sterilize medical devices properly presents a risk of healthcare-associated infections. Studies and reports have indicated that inadequately sterilized medical devices are one of the causes of a higher rate of healthcare-associated infections in developing countries. Steam sterilization (autoclaving) is the most widely used method for sterilization and is considered the most robust and cost-effective method for sterilization of medical devices. The effectiveness of steam sterilization can be measured using biological indicators. A literature search was undertaken to understand the effectiveness of autoclaving in sterilizing reusable medical devices in healthcare facilities across the globe. Studies using biological indicators for measuring the effectiveness of autoclaving were obtained. Failures of steam sterilization practices were identified and discussed as a means of identifying factors that might be associated with the ineffectiveness of steam sterilization practices between different countries. The number of studies measuring the effectiveness of steam sterilization is small, and few evaluate the effectiveness of steam sterilization specifically in developing countries. There are fewer studies on higher level healthcare facilities than dental facilities. More evidence about the effectiveness of autoclaving in healthcare facilities is needed to draw firm conclusions, but the data suggest that there are inadequacies in autoclave procedures and operator education.
\end{abstract}

Key words: Steam sterilization; biological indicators; healthcare-associated infections; evaluation.

J Infect Dev Ctries 2019; 13(10):858-864. doi:10.3855/jidc.11433

(Received 12 March 2019 - Accepted 03 August 2019)

Copyright (C) 2019 Panta et al. This is an open-access article distributed under the Creative Commons Attribution License, which permits unrestricted use, distribution, and reproduction in any medium, provided the original work is properly cited.

\section{Introduction}

Healthcare-associated infections (HAIs) are "infections occurring in a patient in a hospital or other healthcare facility in whom the infection was not present or incubating at the time of admission" [1]. Hospitalized patients in both developed and developing countries acquire HAIs at a proportion of $7 \%$ and $10 \%$ respectively [2]. The sources of HAIs could be from the patients themselves, from healthcare personnel, from medical equipment/devices, from healthcare environment, or from visitors [2]. Surgical site infection (SSI) is the most frequent HAI in developing countries; between 1995 and $2010,1.2 \%$ to $23.6 \%$ of procedures resulted in SSIs in developing counties, whereas the incidence was very much lower $(1.2 \%$ to $5.2 \%)$ in developed countries [2]. In addition, the rate of hospital acquired neonatal infections in developing countries has been reported to be 3-20 times higher than in developed countries [3].

HAIs can prolong a patient's stay in hospital, cause long-term disability, increase the financial burden for health systems, increase costs for patients and their families, and can result in deaths [2]. It has been estimated that the financial loss in Europe due to HAIs is about $€ 7$ billion/year (approx. US\$7.5 billion) and in the USA approx. US\$ 6.5 billion in 2004 [2]. Similarly, estimates suggest that HAIs may take up as many as 2 million bed-days per annum in Australia [1]. Importantly, a considerable proportion of infections caused by drug resistant microorganisms are HAIs [4$6]$ - this has implications for the spread of resistant bacterial strains.

Medical devices are commonly used in healthcare for diagnosis, prevention, treatment and monitoring of diseases and injuries. After use they may be contaminated with microorganisms including, Staphylococcus spp., Micrococcus spp., Diphtheroids, Bacillus spp., Gram-negative rods, fungi and yeasts [711]. Indeed, coagulase-negative Staphylococcus spp., Escherichia coli, Pseudomonas spp., Stenotrophomonas maltophilia, Acinetobacter baumannii complex, Cladosporium spp., Aspergillus 
spp., and/or Candida spp. have been recovered from surgical instruments after clinical use [12]. Used medical devices are sterilized before reuse for invasive clinical procedures; however, if the devices are not properly sterilized prior to their reuse, microorganisms (including pathogens) might be transferred to tissues or mucous membranes during invasive clinical procedures such as surgery, resulting in HAIs. Reuse of medical devices is driven by major cost savings across medical disciplines [13]. However, if sterility of reused medical devices is not assured, the potential cost of HAIs will affect the cost-benefit ratio. Clearly, in the present scenario of burgeoning HAIs, effective sterilization of medical devices before reuse is of paramount importance.

Reporting of HAIs associated with medical devices is relatively poor globally and there have been comparatively few investigations of device-associated infections [14]. An investigation into a sudden increase in SSI rates following 'clean' surgery in the UK showed that post-sterilization contamination of surgical instruments was responsible [15]. In the USA, Tosh, et al. conducted a case-control study to investigate the source of seven SSIs that occurred after arthroscopic procedures at a Hospital in Texas in 2009 and found that SSIs caused by $P$. aeruginosa were likely related to surgical instrument contamination during reprocessing [16]. Inadequate reprocessing of medical devices has been considered as one of the factors contributing to higher rates of HAIs in developing countries [2,3,17]. An acute hepatitis outbreak in Gujarat in India and a high prevalence of anti-hepatitis $\mathrm{C}$ seropositivity $(28.9 \%)$ in a Chinese village were both attributed to inadequately sterilized medical equipment, including needles and syringes [18,19].

Autoclaving is the most widely used method for sterilization worldwide and is considered the most robust and cost-effective method for sterilization of medical devices [20,21]. The effectiveness of sterilization is defined by the probability of a viable microorganism being present on a sterilized medical device; this is termed the Sterility Assurance Level (SAL). A SAL of $10^{-6}$ is a requirement for reuse of medical devices $[22,23]$. Different indicators have been developed to ensure the effectiveness of sterilizing procedures including autoclaving. The effectiveness of autoclaving can be monitored using chemical or biological indicators - monitoring each autoclave cycle is recommended by most guidelines and standards $[24,25]$. Biological indicators are considered the most reliable monitor of sterilization effectiveness [26,27]. Biological indicators are based on microorganisms, e.g.
Geobacillus stearothermophilus spores that are killed at the standard autoclave temperature $\left(121^{\circ} \mathrm{C}\right)$. The indicator is placed inside the autoclave along with the medical devices to be sterilized. Once the sterilization cycle is complete, the indicator is removed and incubated in a culture medium at an optimum temperature for growth of the indicator organism. If the organism grows, the sterilization cycle is considered to have been ineffective, and the medical devices are also considered unsterile.

This review was carried out to understand the current effectiveness of autoclaving in sterilizing reusable medical devices in healthcare facilities across the world. The review was expected to help identify factors likely to be associated with steam sterilization failures. Identifying key knowledge gaps in steam sterilization of medical devices was also an objective of the review. The findings of the review were expected to help improve steam sterilization practices in healthcare facilities and contribute to the prevention of HAIs.

\section{Methodology}

Studies on the effectiveness of steam sterilization practices were sought from the following databases, Google Scholar, MEDLINE and CINAHL using the following keywords, 'infection control', 'sterilization', 'decontamination', 'autoclave', 'hospital', 'healthcare', 'medical devices', 'reuse', 'patient safety', 'reprocessing', and 'monitoring'. At first, articles found in the data bases were screened based on their title and abstract. Full-text of original articles (i.e. not reviews or guidelines) published after 1980 in English were read and screened. Only studies which used biological indicators to evaluate effectiveness of autoclaving, included detailed information about methods and were published after 1980 in English were included in the review. Bibliographies from the retrieved articles were used to identify further relevant publications meeting these criteria. Articles reporting the effectiveness of sterilization methods other than autoclaving were excluded from the review.

Full-texts of the articles included in the review were read carefully and relevant data were extracted from each of the articles. First author's name, year of publication, location (i.e. country) of study, type of healthcare facilities included in the study and steam sterilization failure proportions were extracted from each of the articles and included in the review. In addition, detailed information about methods (i.e. sample size, type of biological indicator unit used for evaluating effectiveness, microorganism used in biological indicator unit, number of spores contained in 
each biological indicator unit and method of administration of the biological indicator unit) were also extracted from the articles. The data extracted from the articles were then tabulated.

\section{Results}

Altogether 253 articles on decontamination and reprocessing of medical devices in healthcare facilities were retrieved using the search criteria described in Methods. Of these $5.9 \%(n=15)$ reported studies on the effectiveness of autoclaving in healthcare facilities [2842]. A summary of these studies is shown in Table 1; these studies showed sterilization failure proportions between $1.5 \%$ (dental practice, UK) and $43 \%$ (dental practice, USA). Of the 15 studies shown in Table 1, 12 were undertaken in dental practices and 3 were undertaken in general or specialized healthcare facilities (e.g. eye care hospitals).

Among the studies measuring the effectiveness of autoclave cycles in healthcare facilities, some variations in the biological methods used for measuring the effectiveness were observed. Some studies used spore strips (i.e. bacterial spores on paper strips) for measuring the effectiveness, while others used ampoules with bacterial spores in culture media. Most of the studies used spores of G. stearothermophilus as an indicator for measuring the effectiveness of sterilization; however, others used a mixture of $G$. stearothermophilus and Bacillus subtilis spores [31,42]. Also, the number of spores contained in the biological indicator units used was not reported in most of the studies. The number of autoclave cycles tested varied considerably between studies, ranging from 22 to 2437 autoclave cycles $[28,36]$.

\section{Discussion}

Evidence for autoclave effectiveness

Globally, the number of published studies measuring the effectiveness of autoclave practices using biological indicators is small $(n=15)$; the reason for this is uncertain. The number of such studies is small in both developed and developing countries. In developed countries, there are strict national regulatory requirements, use of sophisticated technologies, provision of trained sterilization staff and regular infection control audits. This situation could have created a degree of complacency among researchers in these countries, meaning that they do not see the necessity for such studies. However, medical deviceassociated infections have been reported from developed countries; therefore, monitoring and documenting the effectiveness of autoclave practices in these countries cannot be neglected. On the other hand, most developing countries are likely dependent on less sophisticated autoclaves and under-skilled operators, which might lead to sterilization failures. Clearly, evidence for the effectiveness of sterilization practices in these countries is crucial.

From the global literature there appears to be no declining trend in sterilization failures. A study published in 1998 reported a low sterilization failure proportion in dental practices in the UK [33].

Table 1. Summary of studies using biological indicators to assess the effectiveness of steam sterilization.

\begin{tabular}{|c|c|c|c|c|}
\hline Author (year) & Country & $\begin{array}{l}\text { Type of } \\
\text { healthcare } \\
\text { facilities }\end{array}$ & $\begin{array}{l}\text { Autoclave } \\
\text { failure } \\
\text { proportion }\end{array}$ & Remarks \\
\hline $\begin{array}{l}\text { Skaug (1983) } \\
\text { [28] }\end{array}$ & Norway & Oral surgeries & $22.7 \%$ & $\begin{array}{l}\text { Oral surgeons were provided with biological indicator units and } \\
\text { instructions for using them (type and number of spores contained in } \\
\text { the indicator unit were not reported). Altogether, } 22 \text { autoclaves were } \\
\text { tested twice using } 4 \text { biological indicator units for each sterilization } \\
\text { cycle. }\end{array}$ \\
\hline $\begin{array}{l}\text { Palenik et al. } \\
\text { (1986) [29] }\end{array}$ & US & $\begin{array}{l}\text { Endodontic } \\
\text { offices }\end{array}$ & $6.1 \%$ & $\begin{array}{l}\text { Practitioners were provided with two biological indicator strips and } \\
\text { instructions for using them (each strip containing spores of } B \text {. } \\
\text { subtilis and } G \text {. stearothermophilus; number of spores contained in } \\
\text { the strip was not reported). Altogether, } 66 \text { autoclaves were tested } \\
\text { twice using one indicator strip for each sterilization cycle. }\end{array}$ \\
\hline $\begin{array}{l}\text { Scheutz and } \\
\text { Reinholdt } \\
\text { (1988) }[30]\end{array}$ & Denmark & Dental offices & $4.5 \%$ & $\begin{array}{l}\text { Each dental practice was provided with five biological indicator } \\
\text { units (type and number of spores contained in the indicator unit were } \\
\text { not reported). Altogether, } 314 \text { dental offices tested their autoclaves } \\
\text { five times using the indicators provided. }\end{array}$ \\
\hline $\begin{array}{l}\text { Messieha et } \\
\text { al. (1989) [31] }\end{array}$ & Ohio, US & Dental offices & $43.0 \%$ & $\begin{array}{l}\text { Dental practitioners were provided with two biological indicator } \\
\text { strips (each containing } 1.3-1.6 \times 10^{6} \text { spores of } B \text {. subtilis and } 1.3- \\
1.6 \times 10^{5} \text { spores of } G \text {. stearothermophilus) and instructions for using } \\
\text { them. Altogether, } 194 \text { autoclaves were tested once using the } \\
\text { indicators provided. }\end{array}$ \\
\hline
\end{tabular}


Table 1 (continued). Summary of studies using biological indicators to assess the effectiveness of steam sterilization.

\begin{tabular}{|c|c|c|c|c|}
\hline Author (year) & Country & $\begin{array}{l}\text { Type of } \\
\text { healthcare } \\
\text { facilities }\end{array}$ & $\begin{array}{l}\text { Autoclave } \\
\text { failure } \\
\text { proportion }\end{array}$ & Remarks \\
\hline $\begin{array}{l}\text { McErlane, } \\
\text { Rosebush and } \\
\text { Waterfield } \\
\text { (1992) [32] }\end{array}$ & Canada & Dental offices & $2.3 \%$ & $\begin{array}{l}\text { Dental offices were provided with } 24 \text { biological indicator strips } \\
\text { (each containing } 1.2-2.2 \times 10^{4} \text { spores of } B \text {. stearothermophilus and } \\
1.3-2.1 \times 10^{6} \text { spores of } B . \text { subtilis) and instructions for using them. In } \\
\text { total, } 502 \text { dental offices participated in the study and tested } 1,190 \\
\text { autoclave cycles with the indicators provided during a period of one } \\
\text { year. }\end{array}$ \\
\hline $\begin{array}{l}\text { Burke et al. } \\
\text { (1998) [33] }\end{array}$ & UK & $\begin{array}{l}\text { Dental } \\
\text { practices }\end{array}$ & $1.5 \%$ & $\begin{array}{l}\text { Dental practitioners were provided with three biological indicator } \\
\text { strips and instructions for using them (type and number of spores } \\
\text { contained in the indicator strips were not reported). In total, } 401 \\
\text { practices tested their autoclaves twice using the indicators provided. }\end{array}$ \\
\hline $\begin{array}{l}\text { Skaug et al. } \\
\text { (1999) [34] }\end{array}$ & Norway & $\begin{array}{l}\text { Dental offices / } \\
\text { clinics }\end{array}$ & $\begin{array}{l}8.8 \%(1985) \\
1.8 \%(1996)\end{array}$ & $\begin{array}{l}\text { In the } 1985 \text { study, practitioners were provided with four biological } \\
\text { indicator units and instructions (type and number of spores contained } \\
\text { in the indicator unit were not reported); altogether, } 212 \text { autoclaves } \\
\text { were tested once using the indicators provided. In the } 1996 \text { study, } \\
\text { practitioners were provided with two sets of three biological } \\
\text { indicator units (each containing } 3.2 \times 10^{5} \text { spores of } G \text {. } \\
\text { stearothermophilus) and instructions; in total, } 163 \text { autoclaves were } \\
\text { tested twice with the indicators provided. }\end{array}$ \\
\hline $\begin{array}{l}\text { Coulter et al. } \\
(2001)[35]\end{array}$ & $\begin{array}{l}\text { England } \\
\text { and Wales, } \\
\text { UK }\end{array}$ & $\begin{array}{l}\text { Primary care } \\
\text { practices }\end{array}$ & $2.0 \%$ & $\begin{array}{l}\text { Practitioners were provided with three biological indicator ampoules } \\
\text { and instructions for using them (each indicator ampoule contained } \\
\text { spores of G. stearothermophilus, but number of spores contained in } \\
\text { the ampoule was not reported). In total, } 302 \text { autoclaves were tested } \\
\text { twice with the indicators provided. }\end{array}$ \\
\hline $\begin{array}{l}\text { Acosta-Gío et } \\
\text { al. }(2002) \text { [36] }\end{array}$ & Mexico city & Dental offices & $6.7 \%$ & $\begin{array}{l}\text { Practitioners were provided with biological indicator strips (each } \\
\text { containing } 10^{5} \text { spores of } G \text {. stearothermophilus and } 1.7 \times 10^{6} \text { spores } \\
\text { of } B . \text { subtilis) and trained in using them. In total, } 61 \text { dental offices } \\
\text { tested } 2,437 \text { autoclave cycles. }\end{array}$ \\
\hline $\begin{array}{l}\text { Kelkar, Bal } \\
\text { and Kulkarni } \\
(2004)[37]\end{array}$ & India & $\begin{array}{l}\text { Eye care } \\
\text { hospitals }\end{array}$ & $12.0 \%$ & $\begin{array}{l}\text { Eleven eye hospitals were supplied with biological indicator strips } \\
\text { (each containing } 10^{5} \text { spores of G. stearothermophilus); however, the } \\
\text { person performing the autoclave testing was not clear. The } \\
\text { autoclaves in the hospitals were tested once each month during a } \\
\text { period of one year. Altogether, } 125 \text { autoclave cycles were tested. }\end{array}$ \\
\hline $\begin{array}{l}\text { Healy et al. } \\
(2004) \text { [38] }\end{array}$ & Ireland & $\begin{array}{l}\text { Dental } \\
\text { practices }\end{array}$ & $11.3 \%$ & $\begin{array}{l}\text { Practitioners were provided with three biological indicator units and } \\
\text { instructions for using them (type and number of spores contained in } \\
\text { the indicator unit were not reported). In total, } 265 \text { autoclaves were } \\
\text { tested twice with the indicators provided. }\end{array}$ \\
\hline $\begin{array}{l}\text { Wai-Kwok } \\
\text { and Chi-Ming } \\
(2007)[39]\end{array}$ & Hong Kong & $\begin{array}{l}\text { Private dental } \\
\text { practices }\end{array}$ & $7.0 \%$ & $\begin{array}{l}\text { Practitioners were provided with two biological indicator ampoules } \\
\text { and instructions for using them (type and number of spores } \\
\text { contained in the indicator ampoule were not reported). In total, } 175 \\
\text { autoclaves were tested once with the indicators provided. }\end{array}$ \\
\hline $\begin{array}{l}\text { Miranzadeh et } \\
\text { al. (2013) [40] }\end{array}$ & $\begin{array}{l}\text { Kashan, } \\
\text { Iran }\end{array}$ & $\begin{array}{l}\text { Government } \\
\text { hospitals }\end{array}$ & $2.9 \%$ & $\begin{array}{l}\text { Autoclaves in six government hospitals were tested with biological } \\
\text { indicators once a week for } 52 \text { weeks (each indicator unit contained } \\
\text { spores of G. stearothermophilus, but number of spores contained in } \\
\text { the unit was not reported). It is not clear whether operators or the } \\
\text { researcher tested the autoclaves. Altogether, } 312 \text { autoclave cycles } \\
\text { were tested. }\end{array}$ \\
\hline $\begin{array}{l}\text { Okemwa, } \\
\text { Kibosia and } \\
\text { Nyamagoba } \\
(2014)[41]\end{array}$ & $\begin{array}{l}\text { Western } \\
\text { part of } \\
\text { Kenya }\end{array}$ & Dental clinics & $31.0 \%$ & $\begin{array}{l}\text { Clinics were provided with biological indicator units and } \\
\text { instructions for using them (each indicator unit contained spores of } \\
\text { G. stearothermophilus, but number of units contained in the ampoule } \\
\text { was not reported). Altogether, } 29 \text { sterilizers were tested once. } \\
\text { However, two of the sterilizers used sterilization techniques other } \\
\text { than autoclaving. Failure proportion specific to the autoclaves was } \\
\text { not provided. }\end{array}$ \\
\hline $\begin{array}{l}\text { Patiño-Marín } \\
\text { et al. (2015) } \\
{[42]}\end{array}$ & Mexico & Dental offices & $21.0 \%$ & $\begin{array}{l}\text { Practitioners were provided with one biological indicator unit per } \\
\text { sterilizer, with instructions for using them (each indicator unit } \\
\text { contained spores of G. stearothermophilus and B. subtilis, but } \\
\text { number of units contained in the ampoule was not reported). In total, } \\
62 \text { autoclaves were tested once. }\end{array}$ \\
\hline
\end{tabular}


However, recent studies from Kenya and Mexico show sterilization failure proportions in dental practices of $31 \%$ and $21 \%$ respectively $[41,42]$. It is noteworthy that the sample sizes for these studies were small compared to many other dental practice studies [38-40]. The majority of the studies obtained in this review showed sterilization failure proportions of $>6 \%$, indicating a need for improvement.

In most studies, the practitioners were given biological indicator strips/ampoules and asked to include them in their autoclave cycles to test sterility and report the results. This methodology relied on the practitioner's appropriate use of the indicators and reliable reporting of the results. The sterilization failure proportions reported by these studies must be interpreted in this context. It is possible that reported failure proportions might be lower than the actual failure proportions in these healthcare facilities. This is because there might be some reluctance among healthcare workers to report very high sterilization failure proportions and tendency to report smaller failure proportions.

\section{Dental practices versus general healthcare facilities}

There are reported cases of infections associated with medical devices in general healthcare facilities $[15,16,43]$, but most of the published sterilization effectiveness studies are concerned with the use of autoclaves in dental practice. Surprisingly, there is little evidence for the effectiveness of autoclave practices in general healthcare facilities (including all levels of hospitals; i.e. primary, secondary and tertiary). Coulter et al. conducted a study on autoclave performance in primary care practices in the UK and found a sterility failure proportion of $2 \%$ using biological indicators [35]. However, this failure proportion was reported by the respondents of the self-administered postal surveys after performing the tests themselves. Clearly, this could have introduced bias.

\section{Autoclaving in developing (low-and middle-income) countries}

There are few studies that have evaluated the effectiveness of autoclaving in developing countries. Studies in India, Kenya and Mexico showed comparatively higher percentages $(12 \%, 31 \%$, and $21 \%$ respectively) of sterilization failure than in Canada, UK, Ireland, Hong Kong and Iran $(2.3 \%, 1.5 \%, 11.3 \%$, $7.0 \%$, and $2.9 \%$ respectively). A gap analysis of infection control in six developing countries revealed that on average $30 \%$ (range $0 \%-100 \%$ ) of the recommended practices for autoclaving were not followed [44]. In another multicentre pilot study conducted in seven developing countries, 90 autoclave cycles were tested using chemical indicators. Of the tested cycles, $22 \%$ showed unacceptable indicator results. However, none of the tested cycles had acceptable temperature and/or pressures readings [45]. These studies clearly demonstrate gaps in autoclave practices in developing countries.

The reuse of medical devices in developing countries is less likely to be regulated with national standards and/or regulatory requirements [46,47]. Limited resources in developing countries may mean that the level of reuse of medical devices in these countries may be higher than in developed countries [48]. However, there are no studies providing exact measurement of the effectiveness of autoclaving practices that cover all categories of hospitals in developing countries. To ensure the sterility of medical devices and consequently reduce the burden of HAIs in these countries, more stringent evidence of the effectiveness of autoclaving is imperative.

\section{Factors associated with steam sterilization failures}

Documented causes of sterilization failures are related to management, staff, sterilization processes, and/or equipment (e.g. autoclave). Absence of strict regulatory requirements, lack of appropriate instructions, lack of supervision, power failures, inadequate knowledge, inadequate sterilization temperature and time, improper packaging and loading, faulty equipment, and inadequate maintenance of equipment were considered as some of the factors associated with sterilization failures $[32,34,40]$. However, statistically significant associations of these factors with sterilization failures were not reported.

\section{Conclusion}

From the data available, it is clear that there is a high proportion of sterilization failure in healthcare facilities in the developing world, but many of the studies relate to dental practices and might not be extrapolatable to higher-level health care facilities. The reasons for sterilization failures are unclear from the published studies. As in the developed countries, the developing countries should have regulations and guidelines in place to ensure appropriate steam sterilization procedures are followed in healthcare facilities. Such procedures need to be validated using appropriate indicators following national/international guidelines. Sterilization is the end result in a process consisting of different steps including cleaning, disinfection, packaging and autoclaving. Standard 
protocols are required for each of these steps and need to be complied with to ensure adequate sterilization. Operator's education on these protocols as an ongoing activity in a clinical setting would impact favourably on the effectiveness of steam sterilization. Further robust studies are necessary to draw firm conclusions about the effectiveness of autoclaving in healthcare facilities of all levels, globally.

\section{References}

1. Lee GM, Bishop P (2013) Microbiology and infection control for health professionals, 5th edition. NSW: Pearson Australia $624 \mathrm{p}$.

2. World Health Organization (WHO) (2011) Report on the burden of endemic health care-associated infection worldwide. Available:

http://apps.who.int/iris/bitstream/10665/80135/1/9789241501 507 eng.pdf. Accessed: 6 February, 2015.

3. Zaidi AK, Huskins WC, Thaver D, Bhutta ZA, Abbas Z, Goldmann DA (2005) Hospital-acquired neonatal infections in developing countries. The Lancet 365: 1175-1188.

4. Sievert DM, Ricks P, Edwards JR, Schneider A, Patel J, Srinivasan A, Kallen A, Limbago B, Fridkin S (2013) Antimicrobial-Resistant Pathogens Associated with Healthcare-Associated Infections Summary of Data Reported to the National Healthcare Safety Network at the Centers for Disease Control and Prevention, 2009-2010. Infect Control 34: $1-14$.

5. Yezli S, Li H (2012) Antibiotic resistance amongst healthcareassociated pathogens in China. Int J Antimicrob Agents 40: 389-397.

6. World Health Organization (WHO) (2012) The evolving threat of antimicrobial resistance - Options for action. Available: https://apps.who.int/iris/bitstream/handle/10665/44812/97892 41503181_eng.pdf?sequence $=1 \&$ isAllowed=y. Accessed: 3 December 2015.

7. Chan-Myers H, McAlister D, Antonoplos P (1997) Natural bioburden levels detected on rigid lumened medical devices before and after cleaning. Am J Infect Control 25: 471-476.

8. Rutala WA, Gergen MF, Jones JF, Weber DJ (1998) Levels of microbial contamination on surgical instruments. Am J Infect Control 26: 143-145.

9. Chu NS, Chan-Myers H, Ghazanfari N, Antonoplos P (1999) Levels of naturally occurring microorganisms on surgical instruments after clinical use and after washing. Am J Infect Control 27: 315-319.

10. Pinto FMG, de Souza RQ, da Silva CB, Mimica LMJ, Graziano KU (2010) Analysis of the microbial load in instruments used in orthopedic surgeries. Am J Infect Control 38: 229-233.

11. Saito $Y$, Kobayashi H, Uetera $Y$, Yasuhara H, Kajiura T, Okubo T (2014) Microbial contamination of surgical instruments used for laparotomy. Am J Infect Control 42: 4347.

12. de Souza Evangelista S, dos Santos SG, de Resende Stoianoff MA, de Oliveira AC (2015) Analysis of microbial load on surgical instruments after clinical use and following manual and automated cleaning. Am J Infect Control 43: 522-527.

13. Kwakye G, Pronovost PJ, Makary MA (2010) Commentary: a call to go green in health care by reprocessing medical equipment. Acad Med 85: 398-400.
14. Southworth P (2014) Infections and exposures: reported incidents associated with unsuccessful decontamination of reusable surgical instruments. J Hosp Infect 88: 127-131.

15. Dancer SJ, Stewart M, Coulombe C, Gregori A, Virdi M (2012) Surgical site infections linked to contaminated surgical instruments. J Hosp Infect 81: 231-238.

16. Tosh PK, Disbot M, Duffy JM, Boom ML, Heseltine G, Srinivasan A, Gould CV, Berríos-Torres SI (2011) Outbreak of Pseudomonas aeruginosa surgical site infections after arthroscopic procedures: Texas, 2009. Infect Control Hosp Epidemiol 32: 1179-1186.

17. Allegranzi B, Nejad SB, Combescure C, Graafmans W, Attar H, Donaldson L, Pittet D (2011) Burden of endemic healthcare-associated infection in developing countries: systematic review and meta-analysis. The Lancet 377: 228-241.

18. Patel DA, Gupta PA, Kinariwala DM, Shah HS, Trivedi GR, Vegad MM (2012) An investigation of an outbreak of viral hepatitis B in Modasa town, Gujarat, India. J Glob Infect Dis 4: 55 .

19. Lu WP, Lin GX, Shi S, Dong JH (2012) Simultaneously high prevalences of hepatitis $\mathrm{B}$ and $\mathrm{C}$ virus infections in a population in Putian County, China. J Clin Microbiol 50: 21422144.

20. Rutala WA, Weber DJ (1999) Infection control: the role of disinfection and sterilization. J Hosp Infect 43 Suppl 1: 43-55.

21. Alfa MJ (2000) Medical-device reprocessing. Infect Control Hosp Epidemiol 21: 496-498.

22. McDonnell G, Sheard D (2012) A practical guide to decontamination in healthcare. Hoboken: Wiley-Blackwell. Available:

https://ebookcentral.proquest.com/lib/canterbury/detail.action ?docID=922358. Accessed: 1 August 2017.

23. Mosley GA (2008) Sterility Assurance Level (SAL): the term and its definition continues to cause confusion in the industry. PMF Newsletter 14: 2-15.

24. (2014) Reprocessing of reusable medical devices in health service organizations. Standards Australia Limited, Sydney and Standards New Zealand, Wellington.

25. Rutala WA, Weber DJ, Healthcare Infection Control Practices Advisory Committee (2008) Guideline for disinfection and sterilization in healthcare facilities. Available: https://www.cdc.gov/hicpac/pdf/guidelines/Disinfection_Nov 2008.pdf. Accessed: 9 February, 2015.

26. Hughes C, Socola G, Hughes M (2009) The gold standard in sterilizer monitoring. Mater Manag Health Care 18: 23-25.

27. Chandrapati S, Yong M (2008) To kill or not to kill-A biological indicator story. Manag Infect Control 78-98. Available:

http://multimedia.3m.com/mws/media/566451O/to-kill-ornot-to-kill-a-biological-indicator-

story.pdf?\&tEVuQEcuZgVs6EVs6E666666. Accessed: 3 March, 2016.

28. Skaug N (1983) Proper monitoring of sterilization procedures used in oral surgery. Int J Oral Surg 12: 153-158.

29. Palenik CJ, King TN, Newton CW, Miller CH, Koerber LG (1986) A survey of sterilization practices in selected endodontic offices. J Endod 12: 206-209.

30. Scheutz F, Reinholdt J (1988) Outcome of sterilization by steam autoclaves in Danish dental offices. Eur J Oral Sci 96: 167-170.

31. Messieha N, Rosen S, Beck F (1989) Evaluation of sterilization monitoring for dental offices in Ohio. Ohio Dent J 64: 8-13. 
32. McErlane B, Rosebush W, Waterfield J (1992) Assessment of the effectiveness of dental sterilizers using biological monitors. J Can Dent Assoc 58: 481-483.

33. Burke F, Coulter W, Cheung S, Palenik C (1998) Autoclave performance and practitioner knowledge of autoclave use: a survey of selected UK practices. Quintessence Int 29: 231-238.

34. Skaug N, Lingaas E, Nielsen Ø, Palenik CJ (1999) Biological monitoring of sterilizers and sterilization failures in Norwegian dental offices in 1985 and 1996. Acta Odontol Scand 57: 175180.

35. Coulter W, Chew-Graham C, Cheung S, Burke F (2001) Autoclave performance and operator knowledge of autoclave use in primary care: a survey of UK practices. J Hosp Infect 48: 180-185.

36. Acosta-Gío AE, Mata-Portuguez VH, Herrero-Farías A, Pérez LS (2002) Biologic monitoring of dental office sterilizers in Mexico. Am J Infect Control 30: 153-157.

37. Kelkar U, Bal AM, Kulkarni S (2004) Monitoring of steam sterilization process by biologic indicators - a necessary surveillance tool. Am J Infect Control 32: 512-513.

38. Healy C, Kearns H, Coulter W, Stevenson M, Burke F (2004) Autoclave use in dental practice in the Republic of Ireland. Int Dent J 54: 182-186.

39. Wai-Kwok A, Chi-Ming N (2007) Autoclave performance in private dental practices in Hong Kong. Hong Kong Dent J 4: 102-112.

40. Miranzadeh M, Sabahibidgoli M, Afshar M, Zarjam R (2013) Study on the biological monitoring of steam sterilizer in Kashan governmental hospitals during 2011. J Appl Sci Environ Sanit 8: 61-66.

41. Okemwa K, Kibosia C, Nyamagoba H (2014) Instrument sterilization practices and monitoring in private and public dental clinics in Eldoret, Nakuru and Kisumu municipalities in Western Kenya. J Ken Dent Assoc 5: 219-226.

42. Patiño-Marín N, Martínez-Castañón GA, Zavala-Alonso NV, Medina-Solís CE, Torres-Méndez F, Cepeda-Argüelles O
(2015) Biologic monitoring and causes of failure in cycles of sterilization in dental care offices in Mexico. Am J Infect Control 43: 1092-1095.

43. Esel D, Doganay M, Bozdemir N, Yildiz O, Tezcaner T, Sumerkan B, Aygen B, Selcuklu A (2002) Polymicrobial ventriculitis and evaluation of an outbreak in a surgical intensive care unit due to inadequate sterilization. J Hosp Infect 50: 170-174.

44. Weinshel K, Dramowski A, Hajdu Á, Jacob S, Khanal B, Zoltán M, Mougkou K, Phukan C, Staneloni MI, Singh N (2015) Gap analysis of infection control practices in low-and middle-income countries. Infect Control Hosp Epidemiol 36: 1208-1214.

45. O'Hara NN, Patel KR, Caldwell A, Shone S, Bryce EA (2015) Sterile reprocessing of surgical instruments in low-and middleincome countries: A multicenter pilot study. Am J Infect Control 43: 1197-1200.

46. Bancroft R (2014) The Role of Standards in Decontamination. In Walker JT, editor. Decontamination in Hospitals and Healthcare. Cambridge, UK: Woodhead Publishing. 42-59.

47. Huys J (2014) Facing the standards gap: An autoclave for the rest of us. Central Service 5: 347-350.

48. Shuman EK, Chenoweth CE (2012) Reuse of medical devices: implications for infection control. Infect Dis Clin North Am 26: $165-172$.

\section{Corresponding author}

Gopal Panta, MSc, PhD

Save the Children International, Nepal Country Office

GPO Box: 3394, Shambhu Marg, Sinamangal, Kathmandu, Nepal

Tel +977 14468130

Fax +977 14468132

Email: gopalpanta12@gmail.com

Conflict of interests: No conflict of interests is declared. 